\title{
J. J. Rousseau'nun Bilim, Etik ve Değerlere Evrensel Bakışı Ekseninde Eğitimi Yeniden Düşünmek
}

\author{
DEMET SAVRUK \\ demetsavruk@gmail.com \\ ORCID ID: 0000-0002-2847-6727
}

\author{
SEYFI KENAN" \\ seyfi.kenan@marmara.edu.tr \\ ORCID ID: 0000-0002-3773-7693
}

Öz: Rousseau'nun evrensel nitelikteki etik dayanakları olan bazı soruşturmaları günümüzde de güncelliğinden bir şey kaybetmemiş, yalnızca farklı izdüşümleriyle şekil değiştirmiştir. Rousseau'nun Birinci Söylev adlı tartışmalı eserini oluşturmasına yol açan, Dijon Akademisi'nin, "bilimler ve sanatların gelişmesi ahlakın düzelmesine yardım etmiş midir?" sorusu, bu bağlamda, araştırmamıza temel oluşturmaktadır. Bugün, bilimsel ve teknolojik girişimlerin sınır tanımayan gelişimi eksenindeki ilerlemeci anlayış, etik alanında bazı tartışmaları da kaçınılmaz olarak gündeme taşımaktadır. Bu durum eğitime dair bazı evrensel hususların, yeniden tartışmaya açılmasına yol açmaktadır. Rousseau'nun belli başlı eserlerini incelediğimiz belge incelemesine dayalı olan bu araştırma, tarihsel bağlam gözetilerek kavramsal analiz yöntemiyle yürütülmüştür. Araştırma sonucunda gerek bilimle etiğin gerekse eğitimle yaşamın, değerler ekseninde bütünleştiği, insanlık onuruna yakışır bir hayatı yeniden düşünmek ve onu kurmak çabası içinde, içsel dayanakları olan evrensel bir etiğe elzem olarak ihtiyaç duyulduğu sonucuna ulaşılmıştır. Bu etik de ancak özgürlük ve müsamaha ekseninde, insana güven ve saygiyı temel alan bir eğitim anlayışla temellendirilebilir.

Anahtar kelimeler: J.J. Rousseau, Eğitim, Etik, Bilim, Değerler

\section{Giriş}

Bilimsel çalışmalar aracılığıyla öngörülse de, beklenmedik ve neredeyse distopik türden bir küresel salgın deneyimiyle karşı karşıya olduğumuz 21.yüzyılın zor günlerinde, insanlığın büyük bir bilinmezlik içinde, hayret verici adaptasyon sürecinden geçtiği görülmektedir. Küresel düzeyde salgına yol açmış olan bu pandemi deneyiminin, birçok yeni ve küresel sorun alanını beraberinde ortaya çıkardığı ve bunların uzun süre güncelliğini koruyacağı da görünmektedir. Gerek gündelik deneyimlerimizin gerekse bilimsel disiplinlerin her alanını ilgilendiren ve acilen gündeme alınarak değerlendirilmesi gereken bu sorun alanlarının en başında şüphesiz ki eğitim hususu gelirken, konuya ilişkin olarak birçok alt boyut

\footnotetext{
*Yüksek Lisans Öğrencisi, Marmara Üniversitesi, Eğitim Bilimleri Enstitüsü.

${ }^{* *}$ Prof. Dr., Marmara Üniversitesi, Atatürk Eğitim Fakültesi.
} 
da ortaya çıkmaktadır. Bu bağlamda eğitimle ilişkili olarak, genelde bilim insanlarının özeldeyse eğitim bilimcilerin etik sorumlulukları, öne çıkan alt başlıklarından biri olarak ele alınabilir.

21. yüzyıl eğitimsel yöntem ve araçları, neredeyse öngörülemeyen muazzam bilimsel ve teknolojik olanaklar etrafında şekillense de bir taraftan zamanının hızına yetişmekte zorlanırken diğer taraftan da bazı etik meseleleri beraberinde getirmektedir. Sürekli ilerlemeyi temel alan bütün bilimsel ve teknolojik yeniliklere rağmen, modern eğitimin başlangıcından bugün geldiğimiz noktaya, bütün bir tecrübe olarak baktığımızda, bazı soruların hâlâ zamanın sınavından geçememiş olduğunu söylersek, herhalde yanılmış olmayız. Bu sorulardan biri de Dijon Akademisi'nin 1749 yılında, ödüllü bir makale yarışması sorusu olarak -18. yüzyıl Aydınlanma ve akıl çağında- gündeme getirmiş olduğu, "bilimler ve sanatların gelişmesi ahlakın düzelmesine yardım etmiş midir?” şeklindeki, etik ve eğitimsel dayanakları güçlü bir soru olarak karşımıza çıkmaktadır. Söz konusu soruya yanıt arayışı ekseninde Rousseau, ilk eseri olan Bilimler ve Sanatlar Üzerine Söylev/Birinci Söylev (1749) eserini oluşturmuştur.

Rousseau'nun bir yandan büyük tepkiler almasına sebep olurken öte yandan bilim çevrelerince ödüllendirilmesine ve tanınmasına da yol açan bu tartışmalı eserden yola çıkarak meseleyi yeniden gündeme getirmek ve günümüz ışığında bir değerlendirme yapmak bugün, özellikle karşı karşıya olduğumuz söz konusu deneyim göz önünde bulundurulduğunda, bizce hala samimi ve gerekli bir çaba olarak görünmektedir. Elbette ki böylesine radikal ve her anlamda evrensel soruların yanıtları kolayca verilemeyecektir. Fakat bu tür soruları sormaya devam etmek, her insanın yaşam deneyimi içinde yüzleşmesi ve/ya en azından çözüm çabasında olması gerektiği bir sorumlulukla birlikte ortaya çıkan etik bağlamıyla, önemini korumaya devam etmektedir.

Söz konusu evrensel sorunu, eğitimsel tecrübenin verili unsurlarından yararlanarak ele alma çabası içinde, modern eğitimin köşe taşlarından biri olan Rousseau'nun görüşleri ekseninde gündeme getirerek, tartışmaya ve değerlendirmeye çalıştık. Gerek Aydınlanma'nın içinden çıkan gerekse ona ciddi eleştiriler getiren bir düşünür olarak Rousseau'nun bakış açısının önemi; kazanılan her şeyin bir bedeli olduğunu vurgulayarak, özgür seçimlerimizin etik dayanaklarının olması gerektiğinin altını çizmesinde yatmaktadır ki bu, zamanı ve mekânı aşan sorgulama, etik tartışmalarında hala güncelliğini korumaya devam etmektedir.

$\mathrm{Bu}$ bağlamda, bu çalışmanın temel amac1; bir taraftan geçmişin izini sürerken diğer taraftan da yönümüzü geleceğe çevirdiğimiz tarihsel bir bakış açısıyla, etik temelli bir değerlendirme yapmak ve bu doğrultuda eğitimsel öngörülerde bulunmak şeklinde ifade edilebilir. Söz konusu amaç doğrultusunda, Rousseau'nun belli başlı eserlerinin incelenmiş olduğu, belge incelemesine dayalı olan bu çalışma, Rousseau'nun felsefesini ve eğitimsel görüşlerini temellendirme çabasını, bugünün değişmeyen evrensel bazı soru(n)ları ışığında yeniden yorumlama girişimi olarak tarihsel ve kavramsal bir çözümleme niteliği taşımaktadır. 


\section{Rousseau’nun Temel Meselesi: İnsan Doğası ve Yozlaşma Sorunu}

Rousseau'nun ideal doğa durumu hakkında, “...artık var olmayan, belki de hiç var olmamış olan ama gene de şimdiki durumumuzu doğru yargılamak için hakkında doğru kavramlara sahip olmamız gereken bir durum" ${ }^{\prime}$ şeklindeki bakış açısında olduğu gibi insanlığın karşı karşıya kaldığı sorunların, insan doğası bağlamı etrafında tartışılması, temel bir hareket noktası oluşturmaktadır. Bir diğer hareket noktasıysa, meselenin toplumsal boyutuna ilişkindir. Damrosch'a göre, Rousseau'nun İkinci Söylev'inde, doğal durumu, düşüncelerimiz, değer yargılarımız ve hatta duygularımız toplum tarafından kendi amaçları için biçimlendirilmeseydi nasıl olurduk, sorusunun ele alındığı bir bakış açısı temsil edilmektedir. ${ }^{2}$ $\mathrm{Bu}$ iki temel hareket noktası, içinde bulunulan durumu aydınlatmada bütün bir perspektif oluşturmaktadır.

Rousseau, bireyi önceleyen anlayışıyla ve toplumsallaşmaya ilişkin yeni bir temellendirme oluşturmasıyla, döneminin hâkim bakış açılarından ayrılmaktadır. Rousseau'nun yeni bir bakış açısı getirdiği ve insan doğası ve toplumsallaşmaya dair görüşleri ekseninde temellendirdiği, eğitime ilişkin fikirleri, "toplumda bürünülen rollerin altında yatan gerçek benliği bulmak ve bu benliğin ortaya çıkmasını sağlayacak eğitim programları ve politik programlar tasarlamak"3 amacı etrafında birleşmektedir. Bu amaç doğrultusunda, bu evrensel meseleyi etik, bilim ve değerler ekseninde tartışmaya açmış olan Rousseau, çağında gördüğü en büyük sorun olarak yozlaşmaya işaret etmektedir.

Rousseau eserlerinde, içinde bulunduğu çağda, Noddings'in yorumuyla, karakteristik olarak zirveye ulaşmış olan ${ }^{4}$ ve giderek yaygınlaşan yozlaşma durumunu şiddetle eleştirmektedir. Rousseau'nun, insandaki gereksiz merakın doğurduğu kötülükler olarak betimlediği, yeryüzü tarihi kadar eski ${ }^{5}$ bu sorunun gerek tarihsel gerekse sosyolojik bağlamda evrensel bir problem olarak, günümüzde de günceliğinden herhangi bir şey kaybetmemiş olduğunu söylemek abartı olarak görülmemelidir. Bu bağlamda, aynı zamanda kurucularından biri olarak yoğun eleştiriler getirdiği Aydınlanma'nın ve modern yaşamın ortaya çıkardığı sorunlara bakış açısı ekseninde, öngörülü bir düşünür olduğunu söyleyebileceğimiz Rousseau eserlerinde, bu yozlaşmanın temelde, kent yaşamı içinde ve toplumsal kurumlar aracılığıyla ortaya çıktığını savunmakta ve bunun temel sebebi olarak da doğadan ve doğal iyiden uzaklaşma durumlarına işaret etmektedir.

Rousseau, Birinci Söylev'inde, içinde bulunduğu dönemde, felsefenin, sanatların ve bilimin softa kişilerce yozlaştırılmasına ve yalnızca kendi bekasına hizmet eden kendinde bir bilim anlayışının oluşmasına karşı rahatsızlığını şiddetli bir üslupla, şu sözlerle dile getirmektedir: "İşte şimdiye kadar üzerinde durulmuş en büyük ve en güzel sorunlardan biri. Bu söylevde, edebiyatın her köşesini sarmış, hatta bazen akademilerin programlarına kadar gelmiş olan metafizik oyunları üzerinde değil, insanoğlunun mutluluğu ile ilgili gerçeklerden biri üzerinde durulmakta-

\footnotetext{
${ }^{1}$ Jean Jacques Rousseau, İnsanlar Arasındaki Eşitsizliğin Kaynağı ve Temelleri Üzerine Konuşma, çev., Erdoğan Başar, Ankara: Anadolu Yayınları, 1968, s.79.

${ }^{2}$ Leo Damrosch, Jean Jacques Rousseau: Huzursuz Dahi, çev., Özge Özköprülü. İstanbul: Türkiye İş Bankası Kültür Yayınları, 2017, s.243.
} 
dır”. ${ }^{6}$ Söz konusu eserinde, birer araç olarak ortaya çıkan bilimler ve sanatların, insan yaşamındaki pratik işlevselliklerine dair bir dizi soru soran, eleştiri ve yorumda bulunan Rousseau, böyle bir konuyu, içinde bulunduğu zamanın ruhuna rağmen tartışmaya açma cüretini göstermektedir.

Rousseau, insana dair temel hususları teğet geçerek, yalnızca kendi varoluşuna hizmet eden bilimsel çabalara karşı tepkilidir. Bu bağlamda Rousseau'nun; skolastik çağın gerçekliğe dair spekülasyonlarına, materyalizme varan rasyonalizme ve her türden dogmatizme karşıt tutumu, gerçekliğin adeta hayatın kendisinden soyutlanarak insanlığa hizmet etmeyen bir boyuta ve elit bir zümrenin dünyasına taşınmasına karşı bir tepki olarak okunabilir. Kendinde bir amaç haline gelen ve adeta, "körler, sağırlar birbirlerini ağırlar" edasıyla belli çevrelerde sürdürülen felsefe, sanat ya da bilimin pratikte, hakikate ulaşmaya ve/ya insanın mutluluğuna bir katkısı olmadığını düşünen Rousseau, nihayetinde, kişinin kendisini tanıyarak potansiyelini ortaya koymasına ve insanlığın çoğunluğunun ortak iyiliğine hizmet etmeyen birtakım uğraşıların bu denli yüceltilmesine karşı ortaya koymuş olduğu çözüm arayışında, bireysel deneyimlere yönelmiştir.

Rousseau'nun bireysel deneyimleri, düşünme ve bilme gibi yalnızca zihinsel edimler olmayıp, birer praksistirler ${ }^{7}$ ve Rousseau'nun praksisinde, insan doğasına uygunluk ve insanlığa yarar birer ölçüt olarak tayin edilmiştir. İçinde bulunduğu çağın en önemli karakteristiği olan akıl vurgusunun aksine, duyu deneyimlerinin önemine dikkat çekmiş olan Rousseau böylelikle, meseleyi özgürlük ve ahlak düzlemlerine taşımış ve bu düşünceleri, insan doğası temellendirmesine ilişkin fikirlerine de kaynak oluşturmuştur.

Rousseau, rahatsızlık duyduğu yozlaşma durumundan yola çıkarak, başta ahlak, eğitim ve politika olmak üzere beşerî bilimlerin birçok alanında eserler vermiştir. $\mathrm{Bu}$ alanlardaki bütün fikirlerini, tek bir merkezden; insan doğasına dair düşüncelerinden yola çıkarak temellendirmiş olan Rousseau, sorunun etik düzleminde kesişen başlangıç noktasından hareket ederek yola çıkmıştır. Rousseau'nun, insan doğasını idealize ederek onu, yeniden başlangıçtaki doğa durumuna, başka bir deyişle, özgür, eşit ve iyi olduğu duruma sahip olabileceği bir toplum düzeni ve bu düzeni oluşturabilecek içsel bir eğitim yöntemini arama çabası içine girmiş olduğu söylenebilir. Bu bağlamda Rousseau'nun, insanlık için evrensel bir etiği eğitim aracılığıyla gerçekleştirmeye çalıştığını söylemek de mümkün görünmektedir.

Birinci Söylev'inde Horatius'tan: "iyi görünüşe aldanırız"8 alıntısıyla söze başlamış olan Rousseau, genel olarak yozlaşma şeklinde nitelendirmiş olduğu söz konusu

\footnotetext{
${ }^{3}$ Damrosch, Jean Jacques Rousseau, s.243.

${ }^{4}$ Nel Noddings, Eğitim Felsefesi, çev., Raşit Çelik. Ankara: Nobel Yayıncılık, 2017, s.13.

${ }^{5}$ Jean Jacques Rousseau, Bilimler ve Sanatlar Üzerine Söylev, çev., Sebahattin Eyüboğlu, İstanbul: Türkiye İş Bankası Kültür Yayınları, 2017, s.11.

${ }^{6}$ Rousseau, Söylev, s.3.

${ }^{7}$ Praksis, insanların, dünyayı ve kendilerini değiştiren kuramsal ve pratik eylemlerinin bütünü demektir. Bkz. Orhan Hançerlioğlu, Felsefe Ansiklopedisi, 1978, s.237.

${ }^{8}$ Rousseau, Söylev, s.5.
} 
problem(ler)e ilişkin olarak geleceğe dair öngörülerini de şu sözleriyle ortaya koymaktadır:

Kimse kendi değerini sayıp dökmeyecek ama başkasının değerini düşürmeye çalışacak. Kimse düşmanına kabaca sataşmayacak ama ustalıklı bir biçimde iftira edecek. Milli kinler sönecek, ama yurt sevgisinden de eser kalmayacak. Hor görülen bilgisizliğin yerine tehlikeli bir inançsızlık gelecek. Birçok aşırılıklar bırakılacak, birçok kötü alışkanlık kötülenecek ama birçokları da erdem adını alacak. Bunların herkeste bulunması ya da varmış gibi gösterilmesi gerekecek. ${ }^{9}$

Rousseau'nun, bu yalnızca görünüşte var olana karşı eleştirel ve adeta saldırgan tutumu, dönemindeki Fransız salon yaşantısındaki aristokrat ve elit zümrenin kendilerini halktan ayrı ve üstün görerek; bilgiyi, edebiyatı, sanatı ve felsefeyi yalnızca kendilerine mâl etmeleri ve alaycı tutumlarına karşı duyduğu rahatsızlıktan kaynaklanmaktadır. Rousseau'nun, bizzat deneyimlemiş olduğu ve samimi bulmadığı bu ortamların, toplumsallaşmaya ilişkin fikirlerini şekillendiren bir zemin oluşturduğu söylenebilir. Rousseau'nun; sade, sahici, samimi ve herkes için ortak yarara/faydaya hizmet eden unsurları, başka bir deyişle herkes için özgürlüğü, eşitliği ve ortak-duyumu (commonsense), bütün felsefesinde temel ilke olarak benimsemesi de bu deneyimlerin bir sonucu olarak ortaya çımıştır.

Rousseau insan doğasının, doğuştan iyi, özgür ve eşit oluşunu savunarak, kötülüklerin kaynağını, hâkim görüşlerin aksine insan doğasına değil, toplum yaşamına bağlamış ve bu düşünceleriyle, insanlığın ilk/doğa durumlarına düşünsel deney yoluyla açıklamalar getirdiği, İnsanlar Arasındaki Eşitsizliğin Kaynağı ve Temelleri Üzerine Konuşma/İkinci Söylev (1755) eserini meydana getirmiştir. Bu yankı uyandıran eseri Levi-Strauss'un, Rousseau'yu modern antropolojinin kurucusu olarak işaret etmesine dahi sebep olmuştur. ${ }^{10}$ Rousseau söz konusu eserinde, toplum hayatındaki yozlaşmanın ve insanın doğa durumundaki ideal pozisyonunun karşılaştırılmasını yaparken gerek Hıristiyanlık inancının gerekse 17. yy. savaş ortamının mirası ve 18. yy.'a nispeten hâkim olan kötücül insan doğası fikrini yerle bir etmiş; içinde bulundukları toplumsal koşullardan yola çıkarak insan doğasını açıklamaya çalışan ve toplum yasalarını bu düzene göre tasarlamak isteyen, dönemin hâkim mantığına da karşı çıkmıştır.

Ayrıca Rousseau, İtiraflar (1782-1789) ve Yalnız Adamın Hayalleri (1782) gibi eserleriyle de modern otobiyografinin kurucusu olarak işaret edilmiştir. İtirafa dayalı eser yazma geleneği her ne kadar batı dünyasına yabancı olmayıp Hıristiyanlık geleneğine dayalı teolojik kökenleri olsa da ${ }^{11}$ Aziz Augustinus'la bir dönüm noktasına ulaşmış olan tinsel nitelikteki otobiyografi, modern ve seküler biçimini Rousseau'yla almıştır. ${ }^{12}$ Bununla birlikte ortaya çıkan; insanın kendi üzerinde,

\footnotetext{
${ }^{9}$ Rousseau, Söylev, s.10.

${ }^{10}$ Damrosch, Jean Jacques Rousseau, s.237.

${ }^{11}$ Michael Foucault, "Kendini Biçimlendirme Teknikleri", Kendini Bilmek: Bir Foucault Semineri, der., Luther H. Martin, Huck Gutman ve Patrick H. Hutton, çev., James Cem Yapıcıoğlu, İstanbul: Profil Kitap, 2019, s.40.

${ }^{12}$ Huck Gutman, “Rousseau'nun İtiraflar'ı: Kendini Biçimlendirme Tekniği”, Kendini Bilmek: Bir Foucault Semineri, der., Luther H. Martin, Huck Gutman ve Patrick H. Hutton, çev., James Cem Yapıcıoğlu, İstanbul: Profil Kitap, 2019, s.135.
} 
kendi düşünmesi üzerine de düşünen bir varlık olduğu düşüncesi ve tanımı, Descartes'in cogitosundan ve John Locke'un tabula rasasından sonra insana, büyük bir iradi ve ahlaki sorumluluk yüklemeye başlamıştır.

Rousseau'nun fikirlerinin tarihsel ve düşünsel etkisine işaret etmek amaciyla değinilen, bireyin ortaya çıkmaya başladığ nizmin başat değerlerini vurgularken diğer taraftan da unutulan, göz ardı edilen ve giderek kendisinden uzaklaşılan birtakım evrensel değerleri ve hakikatleri hatırlama gereksinimini de ortaya çıkarmıştır. Bu noktada Rousseau, dönemin rasyonalist aşırılıklarına ve bunun ortaya çıkardığı/çıkarabileceği tehlikelere dair eleştirilerini ortaya koyarken, insan doğasını ve duyuları öne çıkaran anlayışıyla; temel, ortak, birleştirici ve içsel unsurları, benzer şekilde, aşırı bir eğilimle savunmuştur.

Nitekim aşırılıkları fark etmek, onları eleştirebilmek ve hatta karşıt görüşler ortaya koyabilmek, radikal bir düşünme biçimini gerektirir ki, Rousseau'nun yaklaşık iki buçuk asırlık zaman diliminden sonra dahi tartışılmasına, yine bu düşünce tarzının zemin hazırlamış olduğu söylenebilir. Bu bağlamda, Rousseau'nun zaman zaman aşırı uçlara varan tutumunun, dönemin bir başka uca doğru benzer eğilimde olmasının bir sonucu olduğunu söylemek mümkün görünmektedir. Rousseau'yu her ne kadar kendi başarısız hayat deneyiminin bir çözümlemesini/hesaplaşmasını yapmakla suçlayanlar olsa da Rousseau insana, kendi tarihinin kurucu öznesi olma yetki ve özgürlügüüü verirken de aslında insanın, yaşamında bütün yapabileceğinin kendi hakikatini bulmak deneyimi olduğunu hem doğrudan hem de dolaylı olarak ortaya koymuş olmaktadır. Böylece, bireyin ortaya çıkışını sağlayan ve bireye koşulsuz sorumluluk yükleyen bu düşünsel gelişim süreci, düşünce tarihinde, artık geri dönüşü olmayacak şekilde, "insan” olma özgürlüğünün en büyük teminatı olarak karşımıza çıkmaktadır.

Rousseau'nun savunmuş olduğu; doğal iyilik halinin toplumsal yaşam içinde yozlaşmaya dönüştüğü fikri, tarih boyunca süregelen birey-toplum tartışmalarında yeni bir dönüm noktası yaratmıştır. Rousseau'nun bireye atfetmiş olduğu; eşitlik, iyilik, güven ve sorumlulukla birlikte insan doğasının yeniden ve iyicil bir bakış açısıyla ele alınması sonucunda, hâkim bakış açılarında eksik olan duyular, radikal bir şekilde yeniden gündeme gelmiştir. Bu durumun temel sebepleri arasında; akıl ve Aydınlanma çağının temel karakteristiği olan; aklın orantısız bir biçimde öne çıkarılması ve eğitimde duyu ve duyguların göz ardı edilmesini sıralamak mümkün görünmektedir.

Rousseau'ya göre toplumdaki yozlaşma, yüzeydeki karşıt görünümünün aksine, derinlerde ortaya çıkmaktadır. Nitekim insan söz konusu olduğunda, onu tamamlayan içsel/manevi unsurların göz ardı edilmesi, onların mevcut olmadıkları halde yapay bir şekilde taklidine yol açan; biçimci, materyalist ve yalnızca görünenin gerçek sanıldığı bir yanılsamayla birlikte, bir hakikat sorununa yol açmaktadır. Tarih boyunca metafizik ekseninde tartışılagelen bu ontolojik meseleyi, pratik ve ahlak alanına taşıyan Rousseau böylelikle, deneyim tarihine de kendi imzasını atmıştır. 
Rousseau'nun temellendirmesine göre; insan doğası doğuştan iyiye eğilimli olup her varlık özgür ve eşit olarak dünyaya gelir. Ayrıca insan; iradesi, vicdanı, özgürlügü ve bununla birlikte kaçınılmaz olarak ortaya çıkan sorumluluğuyla, kendine ve doğaya karşı yükümlülük içinde olan, değerli bir varlıktır. İnsana özgü bu nitelikler onu, ahlaki sorumluluğu olan bir özne haline getirirken, eylemlerine dair etkileri önceden düşünen, dikkatli davranan, iradesini kullanan, seçim yapabilen bir varlık olmanın yanında, düşünen ve hisseden bütün bir varlık oluşunun da altını çizmektedir. Şu hâlde, akıl ya da duyuların öncelenmesi gibi zamanın ruhundaki düalist yaklaşımlar bir tarafa, bütüncül bir varlık olarak insanın; kendisiyle çelişmeyen, yaşamını kurarken hakikatle ilişkisini kendi deneyimleriyle tayin edebilen, özgür ve doğal birey kavramının da önü açılmış olur.

Buradaki özgürlük kavramı tıpkı, pratikteki varlığını yasalara borçlu olan ve ancak onlar tarafından sınırlandırılabilen toplumsal özgürlük kavramında olduğu gibi -doğal özgürlügün yerini toplumsal özgürlügün almas $1^{13}$ - feragat edilerek elde edilen bir sınırlandırmaya işaret etmektedir. Burada farklı olan, sınırlandırmanın içsel bir unsurla gerçekleşiyor olmasıdır. Söz konusu içsel unsur, Rousseau'ya göre adaletin teminatı olan vicdandır. Rousseau, toplumsal yaşamda yasaları savunmuş olsa da insana güven ekseninde kişinin, kendi vicdanı aracılığıyla erdemlerini en üst noktaya taşıyabileceği inancındadır.

İnsan eylemlerinin temeline, yargıç olarak vicdanı yerleştiren Rousseau, her şeyden önce insan olma sorumluluğu ve bilincinin kazanılması yönünde bir anlayış sergilemiştir. Dikkati ve iradesiyle seçim yapan insan, değerli bir yaşam sürme çabası haline gelen yaşam deneyiminde, en başta kendisine karşı sorumlu olan bir varlık olarak, belirli bir topluma dahil olmadan önce, insan türüne dahildir. Başka bir deyişle, toplumsal bir varlık olmadan önce insan, "insan" olmalıdır. Bir yurttaş, filozof, bilim insanı, ögrretmen ya da ayakkabıcı olmadan önce "insan" olmalıdır ve insan olma problemi, yozlaşma sorunuyla karşı karşıyadır. O halde insan öncelikle, doğanın ona verdiği yetilerle birlikte koyduğu sınırlamaları da dikkate alarak, doğayı kendine rehber edinmeli ve böylece daha iyi bir toplum idealine, kendi özgür edimlerinden yola çıktığı yaşamıyla dahil olmalı, başka bir deyişle, o toplumu kendi ekseninde yaratmalıdır.

Rousseau, ilgili fikirlerine paralel olan eğitim anlayışında, doğal olarak bireye büyük önem atfetmiştir. Bireyin sorumluluğunu, duyusal unsur olan vicdan ekseninde temellendirmiş olan Rousseau'ya göre, insanların bütün yasalarına karşı doğanın düzenini izleyen vicdan ${ }^{14}$, ancak eylem yoluyla gelişebilir. Nitekim vicdanın edimleri yargılar değil, duygulardır. ${ }^{15}$ Var olmanın hissetmek olduğunu düşünen Rousseau için düşünce, söz ya da eylem, bütüncül bir varlık olarak insanın gelişiminde tek başına yeterli değildir.

İnsanın, yaşamını praksis olarak, sahici ve otantik bir deneyim haline getirebilmesi onun, duyumsama ve düşünmeyle birlikte eyleme geçebilme iradesinde sak-

\footnotetext{
${ }^{13}$ Jean Jacques Rousseau, Toplum Sözleşmesi, çev., Vedat Günyol, İstanbul: Adam Yayınları, 1994, s.30.

${ }^{14}$ Jean Jacques Rousseau, Emile ya da Eğitim Üzerine, çev., Yaşar Avunç, İstanbul: Türkiye İş Bankası Kültür Yayınlar1, 2017, s.369.

${ }^{15}$ Rousseau, Emile, s.405.
} 
lıdır. Böylece Rousseau Emile’de, duyular ekseninde şekillendirmiş olduğu eğitime ilişkin idealist ve natüralist görüşlerini her ne kadar ütopik denebilecek düzeyde ortaya koysa da Mercier'in yorumunda olduğu gibi: "Hiç kuşkusuz kitaptaki gibi kusursuz bir Emile, toplumun mevcut koşullarında mümkün değildir; ama hiç değilse putlar yıkılmıştır". ${ }^{16}$ Böylece Rousseau, ilgili fikirleriyle, deneyime dayalı ve bireyselliklere duyarlı, modern bir eğitim anlayışının temellerini hazırlamiştır.

Rousseau, içinde bulunduğu dönemde, anlaşılması güç ve politik olarak da birçok kesim için -kilise, aristokrasi, saray, vb.- tehlikeli bir konumda durmuştur. Bunun temel nedeni olarak; tarihte, dogmaya karşıt olarak yükselmiş olan aklın, Aydınlanma Çağı'nda ve sekülerizme rağmen, paradoksal bir biçimde, kendisinin dogmaya dönüşme tehlikesi içine girmesinden söz edilebilir. Rousseau, kazanılan her şeyin bir bedeli olduğunu düşünmüş ve Aydınlanma'nın ışığının yakıcı tarafları olduğunu da göstermek istemiştir. İnsanın, doğa durumundan çıkarken vazgeçtiği her şey, elbette ki uygarlık durumunda başka getirilere yol açmıştır; nitekim burada söz konusu olan ödenen bedelin ne olduğudur. Rousseau'ya göre bu bedel, yozlaşmanın da temel sebebi olan özgürlükten vazgeçilmesidir ve açıktır ki Rousseau, bu bedele razı olmamıştır. Bu bağlamda Rousseau'nun çabaları, özgürlük deneyiminin yeniden insanın eline verilebilmesine yönelik, bütün bir çaba olarak ifade edilebilir.

Rousseau İkinci Söylev'inde, toplumsallaşma deneyiminin, hatalı olarak temellendirilmiş birtakım kanunlara dayandırılmasından; Toplum Sözleşmesìnde de gücü elinde tutanların çıkarlarına hizmet etmesinden ötürü, daha en baştan yozlaşmaya neden olduğunu savunmuştur. Fakat Rousseau ne toplum ne de toplumsallaşma karşıtıdır; ayrıca insanın sosyal bir varlık olduğunu da reddetmemektedir. Nitekim bu husus, Emile' de ve İkinci Söylev'de kısmen olsa da Toplum Sözleşmesi'nde açık bir şekilde görünür olmaktadır. Rousseau'nun, kavramlara ve işaret ettiği sorunlara soyut olarak değil, içinde bulunduğu çağın koşullarından yola çıkarak pratik bir bakış açısıyla yaklaşmış olduğunu belirtmek gerekir. Fakat bu bakış açısı, günümüz pragmatist ahlak anlayışı ile de karıştırılmamalıdır.

Rousseau her ne kadar bilim karşıtı bir yaklaşım sergilemiş olsa da şüphesiz ki bu durum, yeni bir etik düşüncenin kapılarını aralayan bir etki yaratmıştır. Rousseau hakkındaki, Bronowski ve Mazlish’in; toplumla ilişkilendirdiği kötülük sorununu laikleştirdiği ${ }^{17}$ ve Arthur Melzer'in de "öz-denetime bağlı bir etikten doğallığa dayalı bir etiğe geçişi kapsayan büyük bir kültürel hareketin temelini oluşturdu ve sorunlarımızı insan doğasının kusurlarına değil de tarihi nedenlere dayandırdı"18 ifadelerinden de anlaşıldığı gibi, Rousseau'nun temelde, iyicil insan doğası fikri ekseninde, bu doğaya uygun etik bir sistem ortaya koymaya çalıştığ söylenebilir.

\footnotetext{
${ }^{16}$ Damrosch, Jean Jacques Rousseau, s.348.

${ }^{17}$ Jacob Bronowski ve Bruce Mazlish, Leonardo'dan Hegel'e Batı Düşünce Tarihi, çev., Elvan Özkavruk Adanır, İstanbul: Say, 2012, s.403.

${ }^{18}$ Damrosch, Jean Jacques Rousseau, s.244.
} 


\section{Bilim ve Etik}

Rousseau'nun, bilim-etik gerilimine ilişkin tepkilere neden olan bazı görüşleri; rasyonalizmin, bilimin, sanatın ve ilerlemenin karşısında olan irrasyonel bir romantik olarak suçlanmasına neden olmuştur. Diğer yandan da bu görüşleriyle modern yaşamın birçok alanında, geri dönülmez ve büyük yeniliklere kapılar açan bir dönüm noktası yaratmıştır. Bu çift kutuplu durumun, çağın karakteristiğiyle birlikte, Rousseau'nun radikal yaklaşımlarından kaynaklandığı söylenebilir.

Nitekim Rousseau Birinci Söylev’inde, bilim-etik meselesine ilişkin olarak şu çarpicı ifadelere yer vermektedir:

Bilim araştırmalarında ne tehlikeler ne çıkmaz yollar vardır! Gerçeğe ulaşmak için, ondan gelecek iyilikten bin kez daha zararlı nice yanlışlıklardan geçmek gerekiyor! ... En iyi niyetlerle yola çıksak bile, bulduğumuz şeyin doğru olduğundan nasıl emin olabiliriz? Bütün bu karışık duygularımız arasında, doğruyu kestirecek olan kıstas ne olacak? İşimiz rast gidip sonunda doğruyu bulsak bile onu iyiye kullanmasını bilebilecek miyiz? İşte işin en güç tarafı budur. ${ }^{19}$

Bahsi geçen soruna ilişkin görüşlerini, çeşitli toplum ve kültürleri kıyaslayarak, tarihsel örneklemelerle ortaya koymuş olan Rousseau'nun, topyekûn bilimleri yahut sanatları kötülediğini ve onların karşısında olduğunu söylemek, iyi niyetli bir yorumla, naiflik olarak nitelendirilebilir. "Ahlakı bilgiden, erdemi de gösteriş ve sanatlardan üstün tutmak gibi mantıksal bir süreç izleyen Rousseau"20, "benim yaptığım bilimi kötülemek değil, erdemli insanlar karşısında erdemi savunmaktır"21 ifadesiyle, duruma ilişkin Sokratvari bir savunma ortaya koymaktadır.

Rousseau'nun yüzeydeki bilim karşıtlığı görünümü, derinlere inildiğinde, etikten yoksun bir bilimin varlığının sorgulanması şeklinde ifade edilebilir. Nitekim Rousseau, bilim ve sanatlardan ziyade onların, -içinde bulunduğu dönemdeki- ele alınış biçimlerine eleştiride bulunmaktadır. Rousseau'nun eleştirisi, başlangıçta birer araç olarak ortaya çıkmış olan bilimsel gelişme ve deneyimlerin, doğanın sınırlarını zorlayarak kontrolsüz bir şekilde ilerlemelerine ve kendilerinde birer amaç olma tehlikesi içine girmelerine yöneliktir. Rousseau'nun söz konusu eleştirisinin gerekçesi; insanların eylemlerinde, ihtiyaç yerine meraktan/tutkulardan yola çıkıyor olmalarıdır.

Rousseau'ya göre doğal olan ihtiyacın yerini arzu/tutku kaynaklı olan merak aldığında, yozlaşma ortaya çıkmaktadır. Her şeyi açılamaya girişen insan, gelişen bilim ve teknolojiyi araç olarak kullanırken bir süre sonra araçlarla amaçları birbirine karıştırmış ve bütünlüğü, gerçekliği ve anlamları yitirmeye başlamıştır. Nitekim insanın açıklama uğraşı bir gereksinim olarak ortaya çıksa da sonu olmayan bu uğraşının ancak ortaya çıarabileceği sonuçları ekseninde değerlendirilmesi gibi, etik bir mesele gündeme gelmektedir. Bu noktada, şeylerin gereklili-

\footnotetext{
${ }^{19}$ Rousseau, Söylev, s.20.

${ }^{20}$ Bronowski ve Mazlish, Batı Düşünce Tarihi, s.405.

${ }^{21}$ Rousseau, Söylev, s.5.
} 
ğini tayin etmede kıstas oluşturmak için başvurulacak yegâne kaynak -yalnızca insana özgü olan- ahlaki doğa olarak ortaya çıkmaktadır.

Her türden dişsal otoritenin ve dogmanın karşısında olan Rousseau'nun, kabul ettiği tek otorite doğadır. Doğa insanlara, tıpkı insanın kendi varoluşunun ona sınırlamalar koyduğu gibi, birtakım sınırlamalar koymaktadır. Rousseau’ya göre insan doğası vicdan aracılı̆̆ıyla konuşmaktadır; vicdanın otoritesiyse içseldir. O halde insan, doğanın sesini susturmamış olması koşuluyla ${ }^{22}$, bütün sınırlamaları vicdanının sesinde bulabilecek bir yetiye sahiptir. Tam da bu nedenle Rousseau'nun eğitimi, küçük yaşlardan itibaren duyuların sağlıklı gelişimini temel alan bir eksende cereyan etmektedir.

Yine de Rousseau'nun, neden merakla ihtiyacı karşı karşıya getirdiği ve meraka bu denli zararlı bir nitelik atfettiği sorusu sorulabilir. Bunu anlayabilmek için Rousseau'nun duyularla ilgili fikirlerinin derinlerine inmek gerekmektedir. Öncelikle Rousseau'nun merak kavramıyla, doğanın sınırlarına karşı yıkıcı dürtüleri içeren bir içgüdüye atıf yaptığı anlaşılmaktadır. Rousseau, tam da bu nedenle, duyguları ayırmak yolunda bir işe girişmiştir.

Rousseau Emile'de, duyguları en temelde; amour de soi ve amour-propre olarak, yani; kendilik sevgisi ve başkalarının gözünden kendimize ilişkin algımız olarak ikiye ayırmaktadır. Rousseau, amour de soi ve amour-propre arasında keskin bir ayrım yapar. Birincisi iyi ve gereklidir, insanın kendini değerli görmesini ve başkalarına merhamet hisleri içerir; ikincisiyse, başkalarına karşı üstün hissetme arzusu ve kibir duygusunu içerir. ${ }^{23}$ Başlangıçta, varlığımızı korumaya ve doğal olarak iyiliğimize yönelik olan içgüdüsel sevgi, duyarlılık yoluyla başka varlıklarla bütünleşmemizi sağlamaktadır. Gurur ya da itibar şeklinde ifade edebileceğimiz, duyarlılığa dönüşememiş bencil (kendine dönük) sevgiyse Rousseau'da, doğal iyilik halinin bozularak yıkıcı tutkulara dönüştüğünün bir ifadesi olarak karşımıza çıkmaktadır.

Rousseau varsaymış olduğu, insanın doğa durumundaki ideal pozisyonundan yola çıkarak, (öz)sevgi -amour de soi- kaynaklı olan doğal ve bozulmamış duyguları, akli yetkinliğe göre öncelemiş ve onları adeta akla rehber yapmıştır. Söz konusu akıl çağında duyuların öncelenmesi, kaçınılmaz olarak tepkileri de beraberinde getirmiştir. Rousseau'ya göre kent yaşamı ve kentsel kurumlar içinde ortaya çıkan yozlaşma sorunu, kişinin özgürlügüüü elinden alan bir tehlike barındırmaktadır. Rousseau'da, kişinin tutkularıyla kendi kapasitesi arasındaki güç dengesini kuramamasi ${ }^{24}$ sonucu ortaya çıkan bu durum kişinin, bir toplum içindeyken, kendisini başkalarının yargıları doğrultusunda biçimlendirme yanılgısından kaynaklanmaktadır. İnsanları, gerek duymadıkları sahte ihtiyaçlarına, bir nevi köle yapan bu durum sonucunda, insanın doğal özgürlüğünü kaybettiğini savunan Rousseau, tam da bu nedenle, insanın özgür doğduğunu fakat yaşamın içinde zincire vurulmuş olduğunu ${ }^{25}$ dile getirme ihtiyacı hissetmiştir.

${ }^{22}$ Rousseau, Emile, s.407.

${ }^{23}$ Nicholas J. H. Dent, A Rousseau Dictionary, Oxford: John Wiley \& Sons, 1992, s.30-36.

${ }^{24}$ Rousseau, Emile, s.70.

${ }^{25}$ Rousseau, Toplum Sözleşmesi, s.14. 
Rousseau, doğaya, insanlara ya da diğer canlılara karşı sınır tanımaksızın bencilce hareket etme durumuna ihtiyaçla sınır koymaktadır. Nitekim ihtiyaç doğaldır ve doğanın yasalarını takip etmek, insanın en önemli sorumluluğu, başka bir deyişle, insan doğasının zorunlu bir yasasıdır. Gerek günümüzde karşı karşıya kaldığımız sorunlardan gerekse geleceğe dair birtakım bilimsel öngörülerden de anlaşıldığ gibi, doğaya karşı yıkıcı eylemlerde bulunduğumuz ve bütün insanlığı ilgilendiren bu sorunun, her geçen gün büyümekte olan etik temelli bir sorun olduğu gerçekleri karşımızdadır. Şu hâlde Rousseau hakkında; bilim ve ilerleme karşıtı yorumunu yapmak yerine, kendinde bilgiyi savunmak derecesine yükselen bilim anlayışının ve dogmaya dönüşme tehlikesi taşıyan bilimsel yöntemin, birtakım değerlere dayalı olarak sınırlandırılması gerektiği düşüncesini savunduğu yorumunu yapmak daha doğru olacaktır.

Rousseau için doğuştan sahip olunan doğal özgürlük en başta, doğanın ve/ya doğamızın sınırlarına saygı göstermekle, onları kabul etmekle başlamaktadır. Bir bakıma özgürlük ancak, doğanın ve eşyanın tabiatının izin verdiği ölçüdeki olanakların farkındalığına göre, sorumluluk ekseninde hareket etmekle pratik edilebilecektir. Bu sınırlandırmadaki ölçütlerin kaynağıysa, insanın iyicil doğa durumundaki kendilik potansiyelinde mevcuttur. Bu potansiyel; doğanın kitabını incelemekle, onun dilini konuşmakla, başka bir deyişle, en başta duyular yoluyla onlara zarar vermeksizin- ve deneyimleyerek açığa çıkabilir. Bu deneyimler rastgele deneyimler olmayıp, aklın duyularla birlikte işe koşulmasıyla ortaya çıkan öğretici deneyimlerdir ve en önemli unsur olarak; hissetmeye, yapmaya, başka bir deyişle, yaşamaya vurgu yapmaktadır.

Elbette ki eylemlerin yol açabileceği sonuçları önceden kestirebilmek için sağlıklı bir muhakemeye ihtiyaç vardır. Rousseau için muhakeme, salt mantık ya da akıl yetisiyle değil, sağlıklı/bozulmamış duyularla, duyarlılık ekseninde eylemde bulunarak gelişebilir. Bu eylemler doğruluğunu ve ahlaki yanını, gücünü sevgiden alan vicdan unsurunda bulmaktadır. Nitekim doğuştan olan vicdan; insanın, kendisi ve diğer insanlarla olan ilişkisinin meydana getirdiği ahlaksal sistemde açığa çıkmaktadır. ${ }^{26} \mathrm{Bu}$ unsur, insana bir araç ya da bir meta gibi değil ancak bir amaç varlığı olarak muamele edilmesini ve aynı duyarlılığın diğer canlılara da yansıtılmasını sağlayacak olan ortak-duyu unsuru olarak da bağlayıcı bir işlevdedir.

Rousseau, tutkuları bedenin; vicdanı da ruhun sesi ${ }^{27}$ olarak tayin etmiş ve doğanın insana; iyiliği tanımak için akıl, onu seçmek için özgürlük ve onu sevmek için de vicdan verdiğini ifade etmiştir. ${ }^{28}$ Böylece vicdanı devre dışı bırakarak, yalnızca akılla hiçbir doğal yasa yapılamayacağ $\mathrm{n}^{29}$ savunan Rousseau'ya göre, eylemlerimizin ahlaki niteliği pratikte ve onlar hakkında verdiğimiz yargılarda görünür olurken; insan, başta kendisine ve ardından bütün varlıklara karşı sorumlu bir varlık olarak, doğasına uygun davranama esasını eylemlerinin temeline koyma sorumluluğunu almış olur. Şu hâlde eğitimde duyular, duygular ve ahlaki sorum-

${ }^{26}$ Rousseau, Emile, s.400.

${ }^{27}$ Rousseau, Emile, s.400.

${ }^{28}$ Rousseau, Emile, s.412.

${ }^{29}$ Rousseau, Emile, s.320. 
luluğun pratik edilmesi yoluyla muhakemenin geliştirilmesi ve böylece, özgür ve bireyselliklere duyarlı bir eğitim anlayışının benimsenmesi gerektiği zorunlu sonuçları ortaya çıkmaktadır.

Konunun, bir diğer hassas boyutu da bilim insanlarının etik sorumlulukları olarak ifade edebileceğimiz; tarihten günümüze değin güncelliğini koruyan ve bütün bilimsel disiplinler açısından dikkate alınması gereken boyutudur. Bilimde hakikat ve kesinlik arayışlarının gerek bilginin doğasına gerekse bilimsel yönteme dair tartışmalı ve uzun bir tarihi-felsefi arka planı olduğu yadsınamaz. Dahası, kimilerince post-truth/hakikat sonrası çağı olarak nitelendirilen günümüzde, bu tartışmaların etik boyutuna ilişkin farklılaşan boyutlardaki izdüşümleri de artan şekilde görünür olmaktadır. Bilimler için etik bir temellendirme yapmak bu araştırmanın kapsamını aşmakla birlikte, meselenin etik sorumluluk boyutuna değinmek gereği ortaya çıkmaktadır.

İdeal bir bakış açısı bizlere, halihazırda bilimle ahlakın uzlaştığını söyleyecektir. Tıpkı Kant'ın, bilimlerden kaynaklanan zararlar hakkındaki düşüncelerinde Rousseau'nun hataya düştüğünü savunduğu ifadelerinde olduğu gibi:

Bütün insanlar eşittir ve sadece ahlaki açıdan iyi olanın geri kalanından üstün bir iç değeri vardır. Bilimler, ahlakın iyileştirilmesi için bir ilkedir. Ahlaki kavramları ayırt etmek, bilgi ve açıklayıcı kavramlar gerektirir. Bilimlerin yayılması insanı yüceltir ve bilgi sevgisi pek çok düşük eğilimi ortadan kaldırır. Hume, en azından onurlu bir adam olmayacak hiçbir bilim adamı olmadığını söylüyor. Öte yandan ahlak bilimlere, bütünlügü geliştirmede, başkalarının haklarına ve kişinin kendi haklarına saygıyı artırmada hizmet eder ve anlayışın kavrayışlarını ileriye götürür. Dürüstlük, bir insanın, hatalarını yazılı olarak ortaya koyarken zayıf noktaları gizlememesini sağlar. Dolayısıyla ahlaki karakterin bilimler üzerinde büyük etkisi vardır. ${ }^{30}$

Fakat pratikte durum başka görünmektedir. Çalışmalarında, bilim-ahlak ve etik etkileşiminin yaklaşık iki yüzyıllık arka planına işaret eden Aközer ve Aközer, II. Dünya Savaşı sonrasında Nazi Almanya'sında, tıbbi deney ve işlemler sırasında işlenen suçların görüldüğ̈̈, Nuremberg Doktorlar Davası'nı ve mahkeme sonucunda, insan hakları hukuku açısından yankı uyandıran ve bilim insanlarının dişsal sorumluluklarına atıf yapan Nuremberg Kodu'nu hatırlatmaktadırlar. ${ }^{31} \mathrm{Ha}-$ kikat ve ahlakın kesiştikleri düzlemden yola çıkılarak, bilim için bir etik temellendirmenin gerekliği ve imkânı ortaya konmaya çalışılan söz konusu çalışmada, 20. yy.'daki insanlık onuruna yakışmayan uygulamalara -"kitle imha silahları, zorunlu ötenazi, çocuklara ötenazi, kitlesel kısırlaştırma, insan deneyleri, psikiyatrinin sosyal ve siyasal kontrol amaçlı kullanılması, vb.”- eleştiriler getirilmekte ve bilim insanlarının, böylesine akıl almaz projelerde bilerek yer almaları, dönemin antiahlaki bakış açılarına dayandırılmaktadır:

\footnotetext{
${ }^{30}$ Immanuel Kant, Lectures on Ethics, der., Peter Heath ve Jerome B. Schneewind, Cambridge: Cambridge University Press, 1997, s.214-215.

${ }^{31}$ Mehmet Aközer ve Emel Aközer, "Bilim Ahlakı Normlarının Etik Temellendirilmesi: Bilim İnsanlarının Dışsal Sorumlulukları”, Yuiksekö̆retim ve Bilim Dergisi, 5/2 (2015), s.111.
} 
Bilim insanlarının içsel ve dışsal sorumluluklarını bilime özgü bir ahlak kodu içinde bir araya getirirken bunları temellendirmek için bilimsel etkinliğin -örneğin, ilerleme gibi- kendi yapısal gerekliliklerine ya da teamüllerine değil, felsefi anlamda etik düşünmeye başvurmak için fazlasıyla gerekçe vardır... Açıktır ki, insanlıkla ve gelecek kuşaklarla dayanışma ilkesini insanın mutlak içsel değerine dayandırmak, bilim insanını, insanları yok etmeye ya da insanların meşru ve ahlaki ereklerini gerçekleştirmelerinin toplumsal veya çevresel önkoşullarını ortadan kaldırmaya yol açabilecek projelere katılmaktan men eder. Popper'ın ifadesiyle 'bilim insanı her türlü inceleme ve araştırmanın pek çok insanın yaşamını etkileyecek sonuçlar doğurabileceğinin her zaman farkında olmalı ve çalışmasının sonuçlarının uygulanmasını temenni ediyor olmasa bile, bu sonuçların olası tehlikelerini ve olası suiistimallerini her zaman önceden görmeye ve önlemeye çalışmalıdır... bilim insanı her şeyden önce insanlığa sadakatle yükümlüdür'. ${ }^{2}$

Her eylemde, insanlık onuruna yakışacak şekilde ve gelecek kuşaklara olan sorumlulukların bilinciyle hareket etmenin gereği, şüphesiz ki en çok da bilim insanının görevi olarak ortaya çıkmaktadır. İnsanın amaç varlığı olduğuna vurgu yapılan bu araştırma Rousseau'nun, adaleti kendisinden çıkarsadığı vicdan unsurunu akıllara getirmektedir. Bu bağlamda Kant'in, biraz önce değinmiş olduğumuz haklı eleştirisiyle işaret ettiği gibi, Rousseau'nun bilimlere karşı bu denli karşıt uç tutumunu; Gill'in, Rousseau'nun yararcı anlayışı ahlak alanına taşımadığ ${ }^{33}$ yorumuyla birlikte, biraz da içinde bulunduğu dönemden kaynaklanan; radikal, romantik ve tepkisel karakterinde aramak gerekir. Nitekim, “doğanın bilinmezliklerinin, bir örtü gibi Tanrı hikmetiyle, bizi bilginin lanetinden korumaya çalıştığını" ${ }^{34}$ iddia eden Rousseau, doğanın dolaysızca tecrübe edilmesindense soyutlanarak bir nesne olarak incelenmesinin, deyim yerindeyse, Pandora'nın Kutusu'nun açılması gibi insanlığı öngörülemeyen tehlikelere doğru götürecek bir bedeli olduğu düşüncesindedir. ${ }^{35}$

İnsan eylemlerinin ahlaki yönünün bilimsel eksende göz ardı edilmesinin yol açtığı/yol açabileceği sorunlar, tarihte dogmaya karşıt olarak yükselen aklın, neredeyse kendisinin dogmaya dönüştüğü bir süreç içinde, kendi yozlaşmasını meydana getirmesiyle ortaya çıkmıştır. Bunun en temel sebebi olarak, duyuların ve doğa yasalarının göz ardı edilmesine işaret eden Rousseau, ilerleme adı altındaki kontrolsüz eylemlerinden yola çıkarak metalaşma tehlikesine giren insanlığı, dünyada ne gibi tehlikelerin beklediğini gösterme çabası içine girmiştir. Bu durum, bilim ve eğitim alanında sorumlulukları olanları, en başta, kendilerini kuşatan ahlaki doğanın getirdiği bütün sorumlulukların farkındalığına davet etmektedir.

\footnotetext{
${ }^{32}$ Aközer ve Aközer, "Bilim Ahlakı Normlarının Etik Temellendirilmesi”, s.116-120.

${ }^{33}$ Natasha Gill, Educational Philosophy in the French Enlightenment: From Nature to Second Nature, England: Routledge, 2010, s.136-137.

${ }^{34}$ Rousseau, Söylev, s.17.

${ }^{35}$ Demet Savruk, "Locke, Rousseau ve Dewey’e Göre Eğitim ve Deneyim İlişkisi”, Yüksek Lisans Tezi, Marmara Üniversitesi, 2019, s.144.
} 
Gerek Rousseau'nun, kişinin ömrünü kapalı bir odada geçirmeyeceği ${ }^{36}$ gerekse Kant'ın insanın bilme ihtiyacı kadar eylemde bulunma ihtiyacı içinde de olduğ ${ }^{37}$ ifadelerindeki bakış açıları bizlere, düşünürlerin yaşam pratiklerine işaret ettikleri bir noktadan hareket ettiklerini göstermektedir. Düşünce ve eylem birlikteliğine işaret eden bir praksis olarak yaşam, eğitimden ve böyle bir eğitim de felsefeden ayrı düşünülemez. Yaşam, eğitim ve felsefe birliğini parçalayan bütün girişimler, sonuçsuz kalmaya ve başarısız olmaya mahkumdur. Bu bağlamda, değer biçebilen ve üstün değerin anlamını kavrayan bir doğaya sahip olan insanın ${ }^{38}$ eğitiminde, değerlere ilişkin/aksiyolojik eğitimsel hedeflerin de gündeme gelmesi kaçınılmaz olmaktadır.

\section{Değerler ve Eğitim}

Söz konusu aksiyolojik boyuttaki hedeflerle, "bilimin ele almadığı, iyi-kötü, güzel-çirkin gibi değerlere" ${ }^{39}$, başka bir deyişle deneyimin etik ve estetiğe ilişkin boyutlarına işaret edilmektedir. Bu boyutlar günümüz eğitiminde değerler yoluyla gündeme gelmektedir. Değer kavramının, tarih boyunca üzerinde fikir birliğine varılmış olan göreceli niteliği, arayışımızın evrensel niteliğine rağmen, birçok boyutta da öznelliğe/yerelliğe işaret etmektedir. Öte yandan, kaçınılmaz bir olgu olarak ortaya çıan küresel dönüşüm, bütün girişimlere rağmen, ihtiyaç duyulan evrensel çözüm önerilerini işaret etmenin çok uzağında durmaktadır.

Dünyada olduğu gibi ülkemizde de özellikle 2000'li yılların başından itibaren gündeme gelen "değerler eğitimi” kavramından, ahlaki gelişim yönünde bir girişim olarak bahsedilebilir. Eğitim programlarından ders kitaplarına değin, önceki yıllara nispeten kendisine somut olarak yer bulduğunu söyleyebileceğimiz "değerler eğitimi” kavramı eksenindeki programların ve örtük birtakım hedeflerin uygunluğuna ve/ya işlevselliğine dair çeşitli araştırmalar ve tartışmalar da artan şekilde gündeme gelmektedir.

İlgili tartışmaların temelinde, elbette ki değer kavramının göreceli niteliğinin yer aldığı söylenebilir. Bunun yanı sıra, çeşitli ideolojik amaçların eğitim aracılığıyla gerçekleştirilmeye çalışılması gibi eskimeyen tartışmalar da ilgili bağlamda gündeme getirilebilir. Aynı zamanda değerlerin, "değer" başlı̆̆ı altında, eğitimin diğer unsurlarından soyut bir şekilde ele alınmaya çalışmasındaki yapaylık da kazanımların kavramsal boyutta kalmasına ve pratikte başarılı olamamasına yol açan bir başka soruna işaret etmektedir. Bu sorunlar biz eğitimcileri, etik ve estetik unsurların, birleştirici bir zeminde, nasıl bir eğitsel yöntem içinde ele alınması gerektiği konusuna götürmektedir.

Bütün göreceli niteliğine rağmen değerler, dünyada çeşitli ülkelerde, belli başlı çekirdek/temel değerler ekseninde toplanmakta ve değerleri, eğitim ve öğretim içerik ve yöntemlerine entegre edilmeye çalışma çabaları görünür olmaktadır. $\mathrm{Bu}$ girişimlerden biri olan, başta UNICEF olmak üzere, UNESCO'nun da içinde bu-

\footnotetext{
${ }^{36}$ Rousseau, Emile, s.343.

${ }^{37}$ Ahmet Arslan, Felsefeye Giriş, Ankara: BB101 Yayınları, 2018, s.60.

${ }^{38}$ Gill, Educational Philosophy, s.131.

${ }^{39}$ Arslan, Felsefeye Giriş, s.30
} 
lunduğu birçok kurum tarafından desteklenen ve 2004 yılında bağımsız bir kuruluş olarak ortaya çlkan Association for Living Values Education InternationalUluslararası Yaşayan Değerler Eğitimi Topluluğu (ALIVE), yaklaşık 30 ülkedeki kuruluşların birliği olup 15 kadar ülkedeki bireyleri, odak noktası veya yerel temas olarak tanımaktadır. ${ }^{40}$

Söz konusu kurum, herkes için daha iyi bir dünya hedefi çerçevesinde oluşturmuş oldukları Yaşayan Değerler Eğitimi/Living Values Education (LVE) adlı programlarında; eğitimin, olumlu değerleri merkezine alması ve bu değerlerin kişilerce yansıtılmasını da hedefi olarak tayin etmesi gerektiğini belirtmektedir. Bu doğrultuda, çocuk ve gençlerin kendilerini keşfetmelerine, geliştirmelerine ve potansiyellerine doğru ilerlemelerine yardımcı olmak için belli başlı değerler, çekirdek değerler olarak tayin edilmiştir: barış, sevgi, saygı, sorumluluk, hoşgörü, dürüstlük, tevazu, mutluluk, yardımlaşma, sadelik, özgürlük, birliktelik veya dayanısma. Yalnızca belirli bir kültür, ırk, arka plan veya dine değil, her insana saygı ve saygınlığ 1 öğreten bu çekirdek değerlerin evrensel değerler olarak tanımlanarak, eğitime entegre edilmesi gerektiğinin altını çizen kurum, bu doğrultuda uluslararası çalışmalar gerçekleştirmektedir. ${ }^{41} \mathrm{Bu}$ ve benzer uluslararası çalışmalar, değer kavramının gerek evrensel niteliğine gerekse yerel bağlamdaki yansımalarına birleştirici bir zeminde yaklaşılabileceğinin örneklerini oluşturmaktadır.

Değerlerin özümsenebilmesinde, açığa çıkabilmesinde, yaşatılabilmesinde ve yenilerinin yaratılabilmesindeki hayati unsur, kişilerin ya da toplumların kendi değerlerini yansıtma ve bunları ifade etmeme biçimlerinin çeşitli kültürlere göre farklılaşabileceğinin bilincinde olmaktır. Nitekim, “öznel olan, nesnel olanla ilişkisi içinde var olur. Böylelikle öznellik ve nesnellik, eylemle bir dayanışma içinde bilgi üreten bir diyalektik birlik oluştururlar". ${ }^{42}$ İşaret edilen bu bağlam, evrensel karşısında yerelin, nesnel karşısında öznelin ve toplum karşısında da bireyin ilişkisinin zorunlu bir karşıtlık içerdiğini değil; bilakis, kendisini ortaya koymasına izin verildiği taktirde bireysel, öznel ya da yerel olanın, ancak evrensellik aracılığıla deneyimlenebileceği ve varlığını sürdürebileceği bir zemine işaret etmektedir.

\section{Estetik Değerler}

Söz konusu duyular olduğunda, onları etkin hale getirecek olan estetik duyuşlar da gündeme gelmektedir. Bu bağlamda, Rousseau'nun çokça tepki alan bazı görüşlerinin, Birinci Söylev'indeki bahsi geçen soruşturusu sonucunda oluşan, sanat karşıtı alımlamalara ilişkin olduğu görünür olmaktadır. Salt aklın, kendi başına hiçbir zaman büyük bir iş başarmadığından yakınarak, ruhun etkileşimleri olmadıkça harekete geçirici olmadığını ifade etmiş olan Rousseau ${ }^{43}$, eğitimde duyulara

\footnotetext{
40 "Living Values Education", Association for Living Values Education, erişim 23 Ağustos, 2020, http://livingvalues.net/.

41 "Living Values Education".

${ }^{42}$ Paulo Freire, Ezilenlerin Pedagojisi, çev., Dilek Hattatoğlu, Erol Özbek, İstanbul: Ayrıntı Yayınları, 2006, s.18.

${ }^{43}$ Rousseau, Emile, s.455.
} 
hitap ederek, onlardan samimi amaçlar ekseninde yararlanmanın öğretici işlevine dikkat çekmektedir.

Bu bağlamda, İlkçağ eserlerindeki yalınlığı ve basitliği överek, eğitimde bu unsurlardan yararlanılması gerektiğini öneren Rousseau'nun, sanatın ve estetik değerlerin karşısında olmak bir tarafa, bilakis onların; lüks, şatafat, gösteriş ve maddi amaçlara değil, hakikate ulaşma ve insanları birbirine yakınlaştırma yolunda samimi ve sahici çabaları olduğu sürece eğitsel işlevine, belki de birçok eğitimciden daha fazla dikkat çekmiş olduğu söylenebilir. Nitekim Rousseau'nun eserlerinin taşıdığı edebi değer de bu bağlamda, görmezden gelinemeyecek bir olgudur.

Rousseau, her alanda benimsemiş olduğu sadelik ve samimiyet ilkelerini sanatta da temel almış ve estetiğin insanları birbirine yaklaştıran işlevini ön plana çıkarmıştır. Bu bağlamda Rousseau'nun, seçkinci ve sofistike olanı her şeyin önüne koyan ya da kurulu düzeni savunan zümrelerden takdir görmesi beklenmemelidir. Rousseau'nun, bu konuda eleştirilere maruz kalmasının en büyük sebebi, daha önce de değinmiş olduğumuz gibi, Fransız salon yaşantısının seçkinci tutumuna karşı tepkisel bir yerde durmasından kaynaklanmaktadır.

Nitekim Rousseau'nun, müziğe olan ilgi ve/ya hayranlığ 1 yanında, yaşamının bir bölümünde müzikle ve operayla ilgilendiğini ve bu alandaki temsillerinin belli düzeyde sergilendiğini İtiraflar'ından (1782-1798) ${ }^{44}$, Ansiklopedi’nin müzik bölümünü yazmış olmasından ve Fransız Müziği Üzerine Bir Mektup (1753) gibi eserler vermesinden de anlamak mümkündür. Bu bağlamda Damrosch, "Rousseau, müziğin yalnızca eğitimli uzmanların icra edebileceği teknik bir beceri olduğu varsayımına isyan ediyor, müziğin temel bir ifade biçimi olduğunu, duygusal ve insani olduğunu öne sürerken, bütün kültürlerin deneyimlerine hitap ediyordu" ${ }^{45}$ ifadesinde bulunmaktadır.

Bütün bunlar yanında, duyulara hitap eden ve onları harekete geçiren deneyimlerin en önemlilerinden olan sanat yapıtları, kimi zaman binlerce sözden yahut onlarca deneyimden daha etkili olabilmektedir. Tıpkı, filmlerinde büyük bir sanatsal bir çabayla insani değerleri hatırlatma amacı güden Tarkovsky'nin, Stanislaw Lem'in aynı adlı eserinden uyarlamış olduğu Solaris (1972) adlı sinema yapıtında, Rousseau'nun ele almış olduğu sorunu şiirsel bir şekilde işlerken kullandığ 1 diyalogda olduğu gibi: "Şu anki anlayışımızı aşan her şeyi yok etmemizi mi istiyorsun? ... Ben koşulsuz bilgiyi savunmuyorum. Bilgi ancak ahlak temelli oldukça gerçektir... Bilimi ahlaki ya da ahlak dışı hale getiren tek etmen insandır. Hiroşima'yı hatırla ki, ahlak dışı bilim üretme!”. ${ }^{46}$ Retorik ve sofistike bir söylemdense; şiirsel, samimi, sade ve sahici bir ifade biçiminin Rousseau için tercih edilirliği kuşkusuzdur.

Değerler, yaşamın/eylemlerin etik ve estetik yönü, sosyal ilişki ve iletişim biçimlerinin de birleştirici unsurlarıdırlar. Gerek insanları birbirlerine yaklaştıran gerekse iletişim ve etkileşimin asgari müşterekleri olarak yaşamı kuşatan her şey, birer

\footnotetext{
${ }^{44}$ Jean Jacques Rousseau, Confessions, der., Ernst Rhys. London: J. M. Dent \& Sons, 1904; İtiraflar I-II, çev., Osman Sarıkaya, İstanbul: Kaknüs, 2018.

${ }^{45}$ Damrosch, Jean Jacques Rousseau, s.229.

${ }^{46}$ Andrei Tarkovsky, Solaris: Sinema Filmi, Rusya: Mosfilm, 1972.
} 
etik ya da estetik değer taşımaktadır yahut taşımalıdır. Değerler insanın, yalnızca insanla değil, eşyayla, doğayla yahut tarihle karşılaşmasının ve etkileşiminin, zamanı ve mekânı aşan birer köprüsüdürler. Bu bağlamda eğitim, kendisi de bir sanat olarak, etik ve estetik bir yörüngeyle kuşatılmıştır. Değerlerden ayrı bir yaşam düşünülemeyeceği gibi değerlerden ayrı bir eğitim de düşünülmemelidir.

Nitekim eğitim alanında gerek klasik idealizmde gerekse günümüz çağdaş eğitim felsefelerinde de görülebileceği gibi değerler; toplumsal yerel değerlerden yola çıkarak evrensel olana doğru uzanan çok geniş bir yelpazede, insanlığın kültürel birikimine ışık tutması ve insanları birbirine yakınlaştırması gibi çeşitli bağlamlarda, daima elzem görülmüştür. Bunun bir yansıması olarak; felsefe, tarih, edebiyat, müzik, resim gibi disiplinlerin -hangi felsefi paradigmaya göre yapılandırılmış olursa olsunlar- eğitim programlarının vazgeçilmez öğeleri olmalarından da kolayca anlaşılmaktadır.

Nihai olarak etik ve estetik değerler, yaşam deneyimler içinde kedini açığa çıkaran potansiyelleriyle hem birer duyuş biçimi hem de birer ihtiyaçtırlar. İnsan duyarlılı̆̆1 ve zarafeti, ruhu beslemeksizin gelişemez ve ruhun ihtiyaçları da bedenin ihtiyaçları kadar elzemdir. Freire'nin de ifade etmiş olduğu gibi "insanlaşma, yalınızca insana özgü bir meseledir" ${ }^{47}$ İnsanlık deneyimiyse ancak insanın haysiyetli ve onurlu davranışıyla taçlandırılabilir.

\section{Sonuç}

Bu çalışmada temel amaç, insan doğası tartışmalarını veya kurgulamalarını gündeme getirmek değil; halen süregelen ve Neoliberal düzende gittikçe büyüyen insanlaşma problemini tartışmaya açmak yoluyla, eylemde arka plana atılmış olan felsefi sorgulamanın işlevselliğini ve gerekliliğini, eğitimle ilişkili olarak yeniden gündeme getirmektir. Nitekim insani değerler üzerinde yeniden düşünmek yoluyla, insan(lı̆̆)ın onur ve haysiyetine yakışır bir yaşamı, uygun bir eğitim anlayışıyla inşa etmek üzerine harekete geçmek, zorunlu bir ihtiyaç olarak ortaya çıkmaktadır. Bu bağlamda sorunsallaştırma, her ne kadar Rousseau'nun Birinci Söylev'inden yola çıkarılarak oluşturulmuş olsa da buradaki tartışma; bilimle etiğin uzlaşmazlığı yahut karşıtlığı ekseninde değil, en temelde, bütünsel bir eğitime biçilmiş olan değer kazandırma rolünün işlevsizliği bağlamında ele alınmıştır.

Bütün bunlardan yola çıkarak, araştırma sonucunda tespit edilen hususları, eğitimin varoluşsal temeliyle ilişkili olarak, 5 başlık halinde şu şekilde ortaya koyabiliriz:

Özgürlük. Bugün eğitimde özgürlügü savunmak; kendi kendine, kendi isteği ve kendi çabalarıyla öğrenmeyi, diğer bir deyişle, deneyime dayalı eğitimi savunmak demektir. O halde deneyime dayalı ve bireyselliklere duyarlı modern eğitimin kurucu düşünürlerinin fikirlerini, bugünün değişen koşulları altında yeniden yorumlamak; içinde bulunulan dönemde karşı karşıya kalınan sorunları anlamak açısından aydınlatıcı olabilir. Ayrıca bu yeniden değerlendirme, ilgili fikirleri, değişmeyen bazı yönleriyle, hala güçlü kılanın ne olduğunu anlamayı da sağlaya-

\footnotetext{
${ }^{47}$ Freire, Ezilenlerin Pedagojisi, s.21-22.
} 
bilir. Nitekim çözüm yolunda, kendimize ait ve/ya uygun olanı ortaya koyabilmek için elzem olan özgürlügü özümseyebilmenin yolu, onu doğru kavramaktan ve onun temellerinin nasıl kurulduğunu anlamaktan geçmektedir.

Değerler. Yaşam ne yalnızca biyolojik ne de yalnızca belli başlı teknik ihtiyaçların giderilmesine yönelik maddi bakış açısıyla kavranamayan, çok yönlü bütünsel bir deneyimdir. Bu deneyimse bir yandan bireyin diğer yandan toplum ve medeniyetlerin, bütünsel olarak da evrenimizin deneyimidir. Bu deneyimi, onun içinde insan eliyle kurulan yapı ve sistemleri etik yahut estetik değerlerden yoksun b1rakmak, bir canlıyı bilerek ve isteyerek sakat bırakmak gibi düşünülebilir; nitekim yaşam her koşulda devam eder.

Aslında nötr bir kavram olan değer, insan edimleriyle bir uçtan diğer uca salınarak veya savrularak olumlu ya da olumsuz anlamlar kazanabilirken, burada güçlü bir aktör olan insan ancak, insani durumu koruma sorumluluğu ve duyarlıllğ ekseninde hareket ettiğinde, onu pozitif bir yörüngeye taşıyabilir. $\mathrm{O}$ halde değerlerin göreceliği eksenindeki köhne tartışmaları bir tarafa bırakarak, yaşamı bütünlük içinde duyumsayabilmenin yollarını aramak ve onları, eğitimle ve bilimsel yöntemlerle yaşatmanın ve sürekli olarak yeniden inşa edebilmenin imkanlarını yaratmak ve sürekli beslemek gerekmektedir.

Bütünlük. Yaşam deneyimlerimizin değerlere ilişkin yönü, özellikle eğitim alanında, soyut ve spekülatif bir şekilde ele alınmak yahut lüks ya da belli bir zümreye ait olarak görülmek yerine, insanın varoluşsal bütünlüğünün bir parçası ve insanlığı birbirine yakınlaştıran unsurlar olarak ele alındığı takdirde işlevsel ve yararlı olabilir. Bu bağlamda, eğitimde bütünlük kavramı, etik ve estetik değerlerin hoşgörü ekseninde uygulamaya geçtiği, bireyselliklere duyarlı eğitim anlayışının evrensel bir ifadesi olarak anlaşılmalıdır. Böyle bir evrensel anlayış yaşamın, yeniden bütün canlılar için değerli ve aynı oranda yaşanabilir zengin olanaklar bütünü olarak hissedilmesine de kapılar açacaktır. Nitekim iyi bir eğitim, bütünlüğü sağlamada gerek değerlerin insan doğasıyla gerekse öğretim içeriklerinin birbirleriyle ve gündelik yaşamla olan sıkı bağlarıyla ilgili olmalı ve onları güçlendirebilecek ortamlar oluşturmaya yönelmelidir.

Evrensellik. Yaşamda ve eğitimde; hoşgörüyü, insana güveni ve onun hikayesine saygıyı temel evrensel değerler olarak bilimle bütünlük içinde ele almak; bireylerin, sahici kendiliklerinin deneyimler ve bu deneyimlerin sorumluluk sahibi bilinçli özneleri aracılığıyla gerçekleşebileceğinin bilincinde olunduğu bir düşünsel zemini gerektirmektedir. Bu zemin ancak, evrensel olanla yerel olanın mutlak bir karşıtlık içinde değil, onların ayrılmaz bir bütün olarak ele alındığı bir bakış açısıyla oluşturulabilir. Söz konusu bakış açısı, özellikle etik meselelerde, pratiklere yön vermek gibi önemli bir işlevi yerine getirebilir.

Bir karşılaşma ve etkileşimler bütünü olan yaşamda gerçek iletişim ve sahici kendilik ancak evrensel bir zeminde kendine yer bulabilir. Böyle bir evrensellik anlayışı bireylerin, en başta kendilerine borçlu olduğu yaşamı ve adaleti, özgürlüklerini ve sorumluluklarını kendi ellerine almaları gerektiğinin bilinci içinde hareket ederek temellendirilebilir. Eğitim kurumunun buradaki kritik rolü; bu iletişim ve etkileşimin oluşabileceği evrensel nitelikteki ortamı; herkes için eşit fırsat ve ola- 
naklar oluşturma çabası içinde meydana getirmektir. Bu ortam her insanın varoluş yolculuğunda farklılaşan çeşitli kendini ifade ve ortaya koyma biçimlerini etik ilke ve sorumluluklar çerçevesinde yaşatmaya; kültürümüzün de önemli bir parçası olan hoşgörüyü özümsemek yoluyla, katkı sağlayacaktır.

Diyalog/İletişim. İnsanları birbirlerine yaklaştıran duyusal etkileşimleri, eğitimde evrensel zemin oluşturan en önemli unsurlardan biri olarak görmek; diyalog ve iletişimi, bir de bu açıdan ele almak, farklılıkların ve bireyselliklerin yaşatılmasının önemli bir teminatı olarak karşımızda durmaktadır. Birlikte yaşamanın ancak, her türden canlıya ve insanın bütün farklılıklarına müsamaha eksenindeki çeşitli diyalog yöntemleriyle -sözlü, sözsüz- mümkün olacağını, bunun yolunun da ancak farkındalık ve duyarlılıktan geçtiğini hatırlamak gerekmektedir. İnsanları bir araya getirenin, tıpkı Rousseau'nun vurgusunu yaptığ 1 gibi, ortak fikirlerden çok ortak duygulanımlar olduğunu; bu duygulanımlar aracılığıla güçlü diyalog ve iletişim kanalları oluşturulabileceğini hatırda tutarak; iletişimi mümkün kılanın, gelişmiş teknolojik iletişim araçlarından ziyade insan olma sorumluluğu taşımak olduğunu ve insanca yaşama onurunun, yasalarla birlikte vicdan ile sağlanabileceğini özümsemek gereklilikleri, yaşadığımız pandemi deneyiminin de bizlere hatırlattığı en önemli derslerdendir.

Nihai olarak; yapıları, sistemleri ve yasaları oluşturanın da onları en iyileştirecek olanın da insan olduğu hatırda tutularak; insan gelişimi, tek yönlü ve yalnızca teknik bir mesele değil, bir insanlaşma problemi olarak ele alınmalıdır. O halde, etik bir yaşam inşası yolunda, bu yaşamı destekleyecek bir eğitimin mümkünlügü sorusu etrafında yeniden düşünmek, eğitim reformlarında bir başlangıç noktası olarak tayin edilebilir. Nitekim, ilgili problemin, yaygınlaştırılabilir ve sürdürülebilir çözümünün, ancak eğitim ve bilimsel yöntemler aracılığıly sağlanabileceği, tarihin bizlere verdiği en güçlü yanıtlardan biri olarak karşımızda durmaktadır. $\mathrm{Bu}$ bağlamda Rousseau'nun, bireysel ve evrensel olanı buluşturduğu ve özgür deneyimlerimizi doğayla sınırlandırdığı bakış açısından hala önemli dersler çıkarılabilir. İnsanlık tarihi ne şimdiden ne de gelecekten ayrı olmayan bütün bir deneyimin bir kesiti olarak incelendiğinde bu dersler, geleceği öngörmeye ve bazı kritik noktaları daha iyi anlamaya katkı sağlayabilir.

\section{Kaynakça}

Aközer, Mehmet ve Emel Aközer. "Bilim Ahlakı Normlarının Etik Temellendirilmesi: Bilim İnsanlarının Dısssal Sorumlulukları”. Yükseköğretim ve Bilim Dergisi. 5/2 (2015): 109-124.

Arslan, Ahmet. Felsefeye Giriş. Ankara: BB101 Yayınları, 2018.

Association for Living Values Education International. "Living Values Education”. Erişim 23 Ağustos, 2020. http://livingvalues.net/.

Barzun, Jacques ve Henry Graff. F. Modern Araştırmacı. Çev., Fatoş Dilber. İstanbul: Kırmızı, 2010.

Bronowski, Jacob ve Bruce Mazlish. Leonardo'dan Hegel'e Batı Düşünce Tarihi. Çev., Elvan Özkavruk Adanır. İstanbul: Say, 2012. 
Damrosch, Leo. Jean Jacques Rousseau: Huzursuz Dahi. Çev., Özge Özköprülü. İstanbul: Türkiye İş Bankası Kültür Yayınları, 2017.

Dent, Nicholas. J. H. A Rousseau Dictionary. Oxford: John Wiley \& Sons, 1992.

Foucault, Michael. "Kendini Biçimlendirme Teknikleri”. Kendini Bilmek: Bir Foucault Semineri. Der., Luther H. Martin, Huck Gutman ve Patrick H. Hutton. Çev., James Cem Yapıcıoğlu. İstanbul: Profil Kitap, 2019: 26-66.

Freire, Paulo. Ezilenlerin Pedagojisi. Çev., Dilek Hattatoğlu ve Erol Özbek. İstanbul: Ayrıntı Yayınları, 2006.

Gill, Natasha. Educational Philosophy in the French Enlightenment: From Nature to Second Nature. England: Routledge, 2010. EBSCO: e-book collection, Marmara e-book Library.

Gutman, Huck. "Rousseau'nun İtiraflar'ı: Kendini Biçimlendirme Tekniği”. Kendini Bilmek: Bir Foucault Semineri. Der., Luther H. Martin, Huck Gutman ve Patrick H. Hutton. Çev., James Cem Yapıcıoğlu. İstanbul: Profil Kitap, 2019: 130-157.

Hançerlioğlu, Orhan. Felsefe Ansiklopedisi: Kavramlar ve Akımlar Cilt 5[Ö-R]. İstanbul: Remzi, 1978.

Kant, Immanuel. Lectures on Ethics. Der., Peter Heath ve Jerome B. Schneewind. Cambridge: Cambridge University Press, 1997.

Noddings, Nel. Eğitim Felsefesi. Çev., Raşit Çelik. Ankara: Nobel Yayıncılık, 2017.

Rousseau, Jean Jacques. Confessions. Der., Ernst Rhys. London: J. M. Dent \& Sons, 1904.

Rousseau, Jean Jacques. İnsanlar Arasındaki Eşitsizliğin Kaynă̆ı ve Temelleri Üzerine Konuşma. Çev., Erdoğan Başar. Ankara: Anadolu Yayınları, 1968.

Rousseau, Jean Jacques. Toplum Sözleşmesi. Çev., Vedat Günyol. İstanbul: Adam Yayınları, 1994.

Rousseau, Jean Jacques. Emile ya da Eğitim Üzerine. Çev., Yaşar Avunç. İstanbul: Türkiye İş Bankası Kültür Yayınları, 2017.

Rousseau, Jean Jacques. Bilimler ve Sanatlar Üzerine Söylev. Çev., Sebahattin Eyüboğlu. İstanbul: Türkiye İş Bankası Kültür Yayınları, 2017.

Rousseau, Jean Jacques. İtiraflar I-II. Çev., Osman Sarıkaya. İstanbul: Kaknüs, 2018.

Savruk, Demet. “Locke, Rousseau ve Dewey’e Göre Eğitim ve Deneyim İlişkisi”. Yüksek Lisans Tezi, Marmara Üniversitesi, 2019.

Tarkovsky, Andrei. Solaris: Sinema Filmi. Rusya: Mosfilm, 1972. 


\title{
Rethinking Education on the Axis of J. J. Rousseau's Universal View of Science, Ethics and Values
}

\author{
DEMET SAVRUK / SEYFi KENAN
}

\begin{abstract}
Some of Rousseau's investigations based on universal ethical foundations have actuality with varieties of repercussions today. One of these was Dijon Academy's, which lead Rousseau to compose his controversial work called First Discourse constitutes the foundation of our research. Today the progressive approaches to scientific and technological developments bring some discussions on ethics to our agenda. This stimulates some universal issues regarding education to re-visit for discussion. This research aims to analytically examine Rousseau's ideas based on his major works in terms of how he universally grounded science, ethics, and values with specific reference to education. As a result of the research, it was concluded that universal ethics with an internal basis is essential within an effort to rethink and establish a life that fosters human dignity. This ethics can only be established by trust and respect for humanity on the axis of freedom and tolerance in education.
\end{abstract}

Keywords: J.J. Rousseau, Education, Ethics, Science, Values 